\title{
CITRUS PARASITES IN THE REGION OF SOUTHERN ALBANIA
}

\author{
Lavdi Hasani \\ Department of Biology, University “Eqrem Çabej”Gjirokastër ,Albania \\ https://doi.org/10.35410/IJAEB.2022.5709
}

\begin{abstract}
In southern Albania is provided most of the citrus production produced in our country. The parasites that affect this type of vegetation are diverse and very different. For the very economic importance of this product we have conducted the study in question. On this basis we have been able to identify some of these parasites and precisely those of a very specific and quite harmful group, often in microscopic forms. This article gives you a brief overview on parasites known as "plant turtles", representatives of U/ O Coccoinea, Order Homoptera. These represent a very specific group of phytoparasitic insects. Among the processes of our work that of determination to species was the most difficult. This is not only due to the limited presence of determinative literature but also due to the fact that a small number of studies have been conducted on this specific group of insects. It should therefore be noted from the outset that our studies on this group of different plant pests are the first and most complete for our country. The paper shows the whole territory where we have spread our study, the collected material, the way of its processing in the laboratory and the determination of the species. During the field work, bioecological data on these harmful species were also collected. By processing the collected data related to this very specific group of pests, a number of conclusions have been reached with values and interest for citrus growers in our region in particular and in Albania as a whole.
\end{abstract}

Keywords: Parasitic insects, citrus, spreads, contamination, Southern Albania.

\section{INTRODUCTION}

Citrus fruits in Southern Albania are widely cultivated due to the fact of dominance of the southern coastal climatic zones throughout the geographical length of our country. In Southern Albania (represented in this case by the districts of Vlora, Saranda, Delvina, Gjirokastra, Tepelena and Përmet), thanks to the Mediterranean climate, citrus fruits are cultivated in each of these territories. In Saranda and Delvina, due to their position in the region in question and the strong influence of the coastal climate on it, citrus fruits are cultivated everywhere. While in the region of Vlora these are cultivated in most of this region as a part of the territory lies in the continental depths and in these mountainous areas already, due to the climatic conditions, it becomes impossible to cultivate these vegetation. [31,34] Also, these restrictions are observed in most of the territory of Tepelena and moreover in that of Përmet. While in these last two districts the cultivation of oranges, lemons and tangerines is very rare; otherwise it happens with the olive tree. This plant has the opportunity and is most widely cultivated in all these regions.

Tangerines occupy the first place in terms of production. Our country produces over 30,000 tons of tangerines a year. [35] In 2019, according to Eurostat, Albania was positioned in 8th place in Europe in terms of annual citrus production. Better than Malta which has a convincingly smaller cultivation area and than Croatia itself, a country that has an unfavorable climate and 
consequently a small cultivation area. Meanwhile, according to the European Union statistics agency, Spain, Italy and Greece lead for citrus overproduction. [36] Due to the warm climate in the regions where they are cultivated, their vulnerability to plant diseases and parasites is very big. Among these parasites (very specific) are the insects in question for which we have conducted this study. On the basis of the economic importance of citrus production in our country as a whole and in the region in particular, this work is of particular importance in this regard. It makes possible the identification and enables the recognition of these parasites (in microscopic mass), spread massively on this type of vegetation in this part of our country. For the realization of this study we have used a considerable literature, mainly in foreign languages as in the Albanian language such an opportunity is extremely limited. This not only as a result of a general condition but mainly due to the fact that the only and most complete study in our country, related to this group of insects, is exactly this one undertaken by us. Based on all this literature we have identified the basic characteristics with determinant value for the representatives of this group of insects. Among them, it should be said that the main value has the plan of building their pygids together with its appendices, among which we are mentioning the most important:

- The variety of pygidial glands and the plan of their placement in it.

- Thorns, types and plan of their placement in the lateral parts of the pygid.

- Anal ring shapes and the channels they carry.

- Pieces, combs, hairs or cerares. The number and plan of their placement.

- Denzores and parafises. Number, size and plan of their placement.

- Reports of body parts, etc. [2-3,5-7,18,21,23-24,27-30]

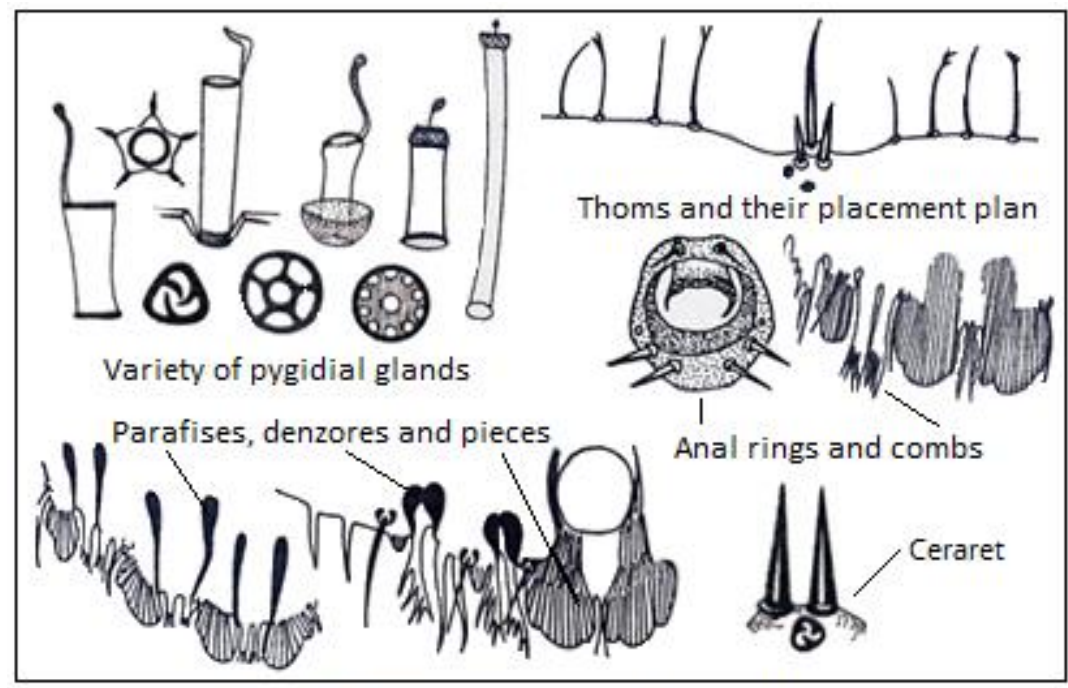

Fig. no.1 - Determinant parts of the pigide 
Vol. 07, No. 01; 2022

ISSN: $2456-8643$

\section{MATERIAL AND METHODS}

For the realization of this study, field expeditions were carried out periodically for a period of 5 years. Several fixed points have been defined in the field for each region. The vegetation at these checkpoints was periodically checked for each season of the year for the presence of these parasites. The fixed material, when it was in the leaves or in the sprig of the plant, was collected together with the plant organ. This material was stored dry in cardboard boxes constructed for this purpose. The material fixed to the plant stalk was removed from them through a scapula and preserved directly in liquid, in $70^{\circ}$ ethyl alcohol. [19,22] In the field, both the cardboard boxes and the conservations test tubes were immediately labeled, marking on them all possible observed identifying data. All this material we have further processed at the zoology laboratory of the Department of Biology of the Faculty of Natural Sciences at the University of Gjirokastra. All this material we have further processed at of the zoology laboratory of the Department of Biology of the Faculty of Natural Sciences at the University of Gjirokastra. Insects are first removed from the wax coating, by inserting them in $10 \% \mathrm{Na} \mathrm{OH}$ solution and further heat treated. [13-14] We then did the dyeing of the material by passing it for a few hours in the fuchsin solution. [7,13] This to enable a more identical view of the morpho-anatomy of their body. The material was then carefully extracted from the fuchsin solution with the help of a scapula and further processed with a mixture of gum arabic with xylene to turn them into permanent microscopic micropreparations. [16-17,19-21,25-26] This is a process that requires a lot of care as during this work many of them may lose you. Species fixed in micropreparats were further determined by observing those sub-binoculars. [1,4,9,21] For the realization of this process, which in itself carries its difficulties, we have relied on the determination keys that we have been able to provid. [10-12,15,32-33]

\section{RESULTS AND DISCUSSIONS}

On the basis of the work done by us, it became possible to identify the presence of a significant number of their species in the vegetation of the citrus group, 30 species, from these pests, representatives of the Suborder Coccoinea of the Order Homoptera. (Tab.no.1) There are only four types of citrus fruits that have been examined: Orange, Tangerine, Lemon and Olive. This group of parasites feeding on plant lymph not only damages the quantity and quality of production but gradually lead to weakening and drying of the plant. Through their specific oral apparatus they pierce the bark of the stalk and that of the leaves (in the area of the leaf veins). Thus they enable the absorption of lymph circulating in the phloem tubes (in the lymphatic ducts). This leads to the weakening of the vegetation and its gradual degradation. On the other hand, during this process, the insect can transmit to the plant a series of viral pathogens, thus accelerating hers final degradation. Different plants we see that are frequented by a different number of parasites. Thus in orang plants we have identified a total of 23 species of parasites (or $42 \%$ of them), in those of mandarin 10 species (or $18 \%$ of them), in those of lemon 10 species (or $18 \%$ of them) and in those of olive 12 species (or $22 \%$ of them), (Graph. no.1). In the whole of the identified species only Saissetia oleae L. and Lepidosaphes beckii New. have been identified in all of the above plant species. 6 species of parasites are found in only three of these plant species. 7 species of parasites are found in only two species of these plants and the other parasites (15 species) only in one of these plant species, (Graph. No. 2).

The vulnerabilities of each plant species to these parasites is presented in Table no.1. 
Tab. no. 1 - Vegetation affected by each species

\begin{tabular}{|c|c|c|c|c|c|}
\hline 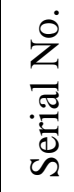 & The name of the parasite & $\begin{array}{l}0 \\
\infty \\
\vdots \\
0 \\
0 \\
0\end{array}$ & 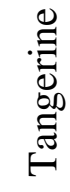 & పี & $: \vdots$ \\
\hline 1 & Icerya purchasi Mask. & + & + & + & - \\
\hline 2 & Pseudococcus citri Risso. & + & + & - & - \\
\hline 3 & $\begin{array}{l}\text { Pseudococcus gahani } \\
\text { Green. }\end{array}$ & + & - & - & - \\
\hline 4 & $\begin{array}{l}\text { Pseudococcus maritimus } \\
\text { Her. }\end{array}$ & + & - & - & - \\
\hline 5 & $\begin{array}{l}\text { Pseudococcus odonidum } \\
\text { L. }\end{array}$ & + & - & - & - \\
\hline 6 & $\begin{array}{l}\text { Asterolecanium alba } \\
\text { Tak. }\end{array}$ & + & + & - & + \\
\hline 7 & Pollinia pollini Costa. & - & + & - & - \\
\hline 8 & Coccus hesperidum L. & + & - & + & + \\
\hline 9 & $\begin{array}{l}\text { Coccus } \\
\text { pseudomagnoliarum } \\
\text { Kuw. }\end{array}$ & + & - & + & + \\
\hline 10 & Pulvinaria betulae $\mathrm{L}$. & - & - & + & - \\
\hline 11 & Saissetia oleae Bern. & + & + & + & + \\
\hline 12 & Ceroplastes rusci L. & + & - & - & + \\
\hline 13 & $\begin{array}{l}\text { Parthenolecanium } \\
\text { persicae F. }\end{array}$ & + & - & - & - \\
\hline 14 & $\begin{array}{l}\text { Eulecanium rugulosum } \\
\text { Arch. }\end{array}$ & + & - & - & + \\
\hline 15 & Parlatoria cinerea Hadd. & - & - & - & + \\
\hline 16 & pergandii & + & + & - & - \\
\hline
\end{tabular}


Vol. 07, No. 01;2022

ISSN: $2456-8643$

\begin{tabular}{|c|c|c|c|c|c|}
\hline 17 & $\begin{array}{l}\text { Lepidosaphes } \\
\text { Pack. }\end{array}$ & + & + & - & + \\
\hline 18 & $\begin{array}{l}\text { Lepidosaphes beckii } \\
\text { New. }\end{array}$ & + & + & + & + \\
\hline 19 & $\begin{array}{l}\text { Aspidiotus nerii (hederae) } \\
\text { Bouch. (Vall.) }\end{array}$ & - & - & - & + \\
\hline 20 & $\begin{array}{l}\text { Aonidiella } \\
\text { Masc. }\end{array}$ & + & - & + & + \\
\hline 21 & $\begin{array}{l}\text { Aonidiella aurantii rac } \\
\text { citrina Coq. }\end{array}$ & + & + & - & - \\
\hline 22 & Aonidiella taxus Leon. & + & - & - & - \\
\hline 23 & Epidiaspis leperii Sign. & + & - & - & + \\
\hline 24 & $\begin{array}{l}\text { Hemiberlesia cyanophylli } \\
\text { Sign. }\end{array}$ & + & - & + & - \\
\hline 25 & $\begin{array}{l}\text { Chrysomphalus ficus } \\
\text { Ashm. }\end{array}$ & + & - & - & - \\
\hline 26 & $\begin{array}{l}\text { Chrysomphalus } \\
\text { dictyospermi Morg. }\end{array}$ & + & - & - & - \\
\hline 27 & $\begin{array}{l}\text { Ephedraspis ephedrarum } \\
\text { Indgr. }\end{array}$ & + & - & - & - \\
\hline 28 & $\begin{array}{l}\text { Abgrallaspis cyanophylli } \\
\text { Sign. }\end{array}$ & - & - & + & - \\
\hline 29 & $\begin{array}{l}\text { Eriopeltis bichtensteinii } \\
\text { Sign. }\end{array}$ & - & - & + & - \\
\hline 30 & $\begin{array}{l}\text { Koroneaspis aegilopes } \\
\text { Kor. }\end{array}$ & - & + & - & - \\
\hline
\end{tabular}

Some species of parasites are found only in one of the above plant species such as: P. gahani Green., P. maritimus Her., P. odonidum L., P. pollini Cost., P. betulae L., P. persicae F. , P. cinerea Hadd., A. nerii (hederae) Bouch. (Vall.), A. taxus Leon., Ch. ficus Ashm., Ch. dictyospermi Morg., E. ephedrarum Indgr., A. cyanophylli Sign., E. bichtensteinii Sign., K. aegilopes Kor. Based on our sub-binocular observations we have been able to sketch and present 
Vol. 07, No. 01; 2022

ISSN: $2456-8643$

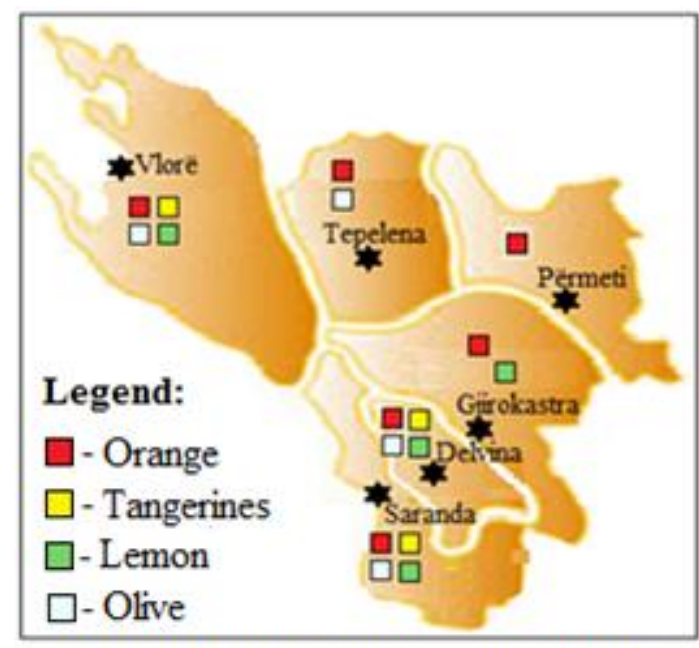

Map. no. 1- Meeting of parasites for each regetation, for each district

the general plans of the pygids of these species, making possible to a very obvious extent the typical differences between them. [21]

\section{RESULTS AND CONCLUSIONS}

1. As shown in Tab. no. 1 the plant most affected by parasites of this group is the orange with 23 species.

From there comes the olive affected by 12 species and finally Mandarina and Lemon with 10 species each. We think this coincides mainly with the larger number of orange and olive plants in relation to those of lemon and mandarin in their plantations in this region. Perhaps one possibility may also be that of the specific liking of the lymph of these plant species. This frequency of susceptibility of these plants to this group of parasites is given in graph no. 1 .

2. In different districts of this region we have found that not in all four types of plants we have identified contaminants. In the districts of Vlora, Saranda and Delvina parasites are found on all four species of this vegetation. In Gjirokastra and Tepelena in two of them and finally in Përmet only on oranges. So the orange plant is found contaminated everywhere, then comes that of olive and lemon in four districts and tangerine in three districts, (Hart. No.1). In this situation we can accept that the plant specifics in the order of orang, olive, lemon and finally tangerine also affect the spread of parasites. 
3.

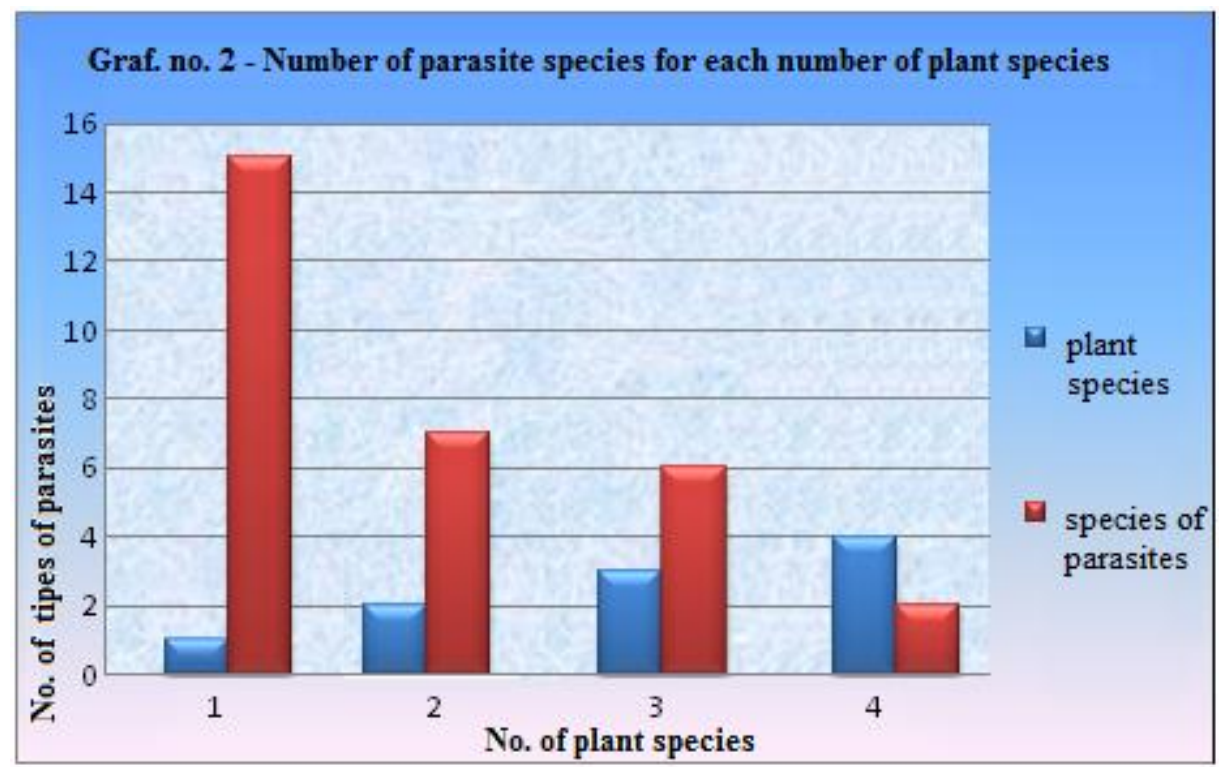

Among the parasites identified by us, most of them (15 species) are found only in one of the above plants, 7 of them in two plant species simultaneously, 6 in three of these plant species simultaneously and finally 2 of their in all (in four species of these plants), graph. no.2. This speaks to the fact that, among these parasites, the most widespread and most polyphagous are exactly the last two species Saissetia oleae L. and Lepidosaphes beckii New. (Found in all four species of plants). Hence come the other 6 species: Icerya purchasi Mask., Asterolecanium alba Tak., Coccus hesperidum L. Coccus pseudomagnoliarum Kuw., Lepidosaphes gloverii Pack. and

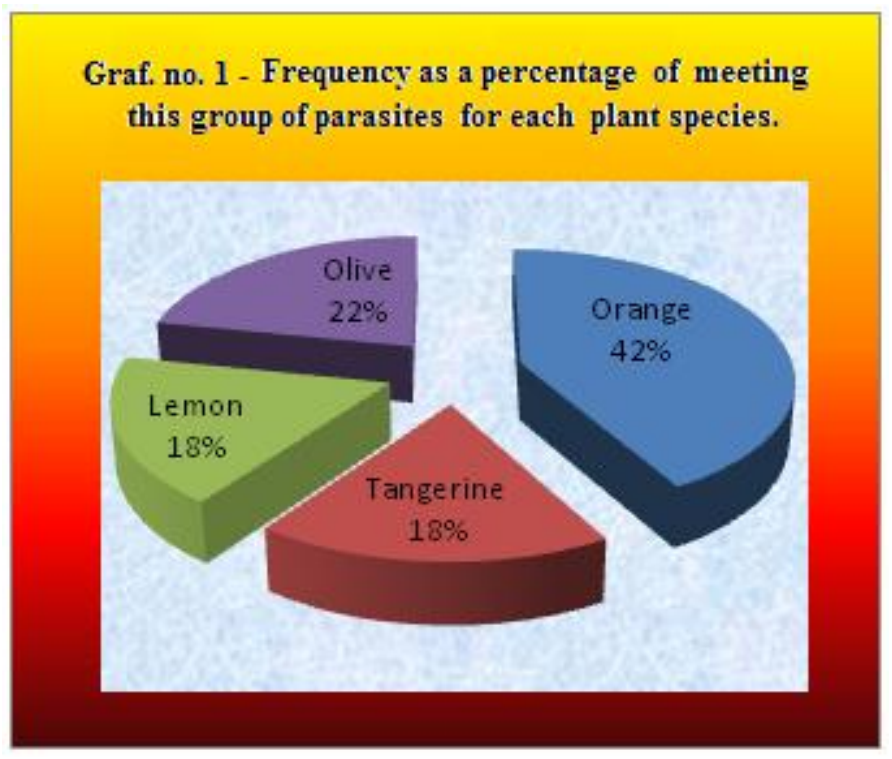


Aonidiella aurantii Masc. (found in three plant species), 7 other species are found in two of these plant species and the remaining 15 species are found in only one of these plant species, graph. no.2.

4. In Tab. no. 2 we see that in mandarin parasites are not found in the vegetation of Gjirokastra, Tepelena and Përmet districts; in lemon in Tepelena and Përmet districts and in olive in Gjirokastër and Përmet districts. We think that this has nothing to do with the characteristics of the species in terms of distribution in the continental latitude of this territory, but with the fact that the plantations with these plant species in the districts in question have not been significant.

This has to do with the lack of plantations with these plant species in these districts, Tab. no.2.

5. Despite the fact that the checkpoints set up were regularly monitored for each season of the year, if we look at Tab. no. 2, not all types are met in every season for every district. We think that this has to do not only with the difficulties of identifying and collecting them but also with the stages of development in which they were located in these districts with different climatic conditions of this region.

Tab. no. 2 - Meeting of parasites in each plant by months (for each district).

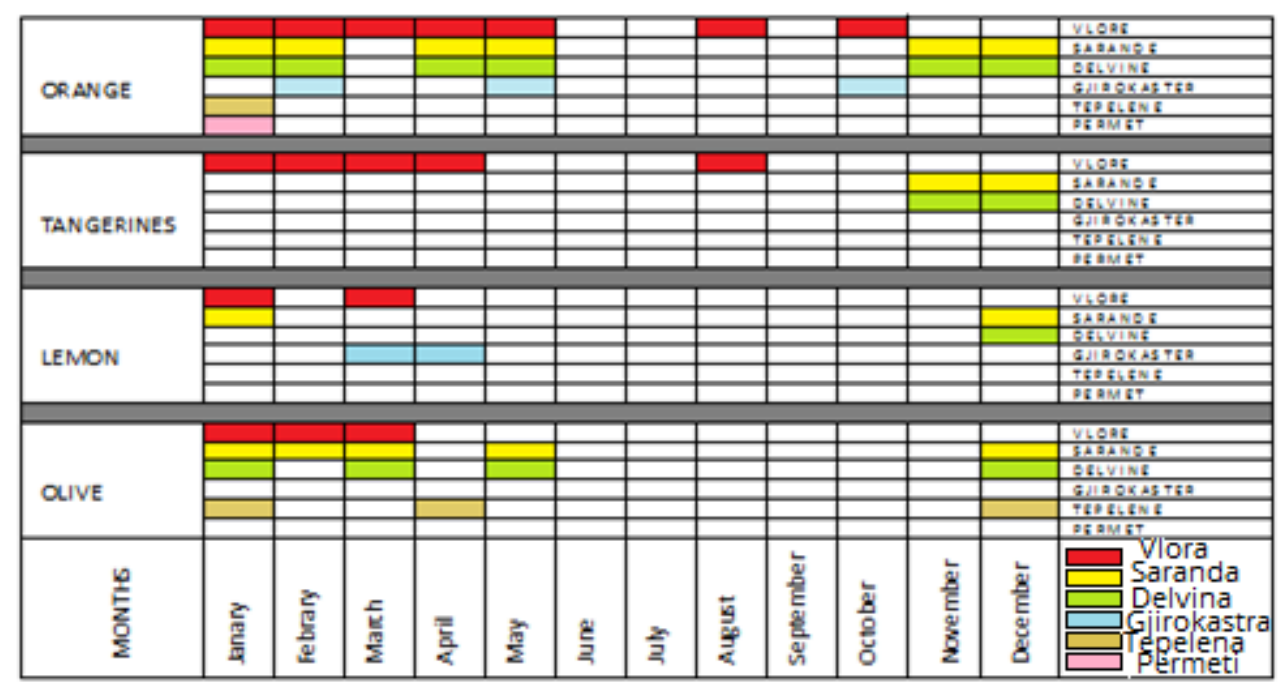

6. As can be seen in table no.2, these parasites, in almost all districts, meet en masse in the winter period (January, February, December) as well as in spring. This is due to the fact that they overwinter as fixed imago complete with eggs and are found more easily. In the spring, as temperatures rise, the larvae of the first motile stage begin to hatch from the eggs they carry. At these stages they can not be collected. For this fact in the period June, July, August (according to the climate) and in September and October we notice their lack in our collections.

\section{RECOMMENDATIONS}

1. It should be borne in mind that two of these species, of this group of insects, are more widespread in this region and namely Saissetia oleae L. and Lepidosaphes beckii New .. 
2. It should also be borne in mind that plant parasites of this group of insects despite being favored by the coastal climate in their massive spread they have a continental extension throughout the region in question.

3. Growers of these crops, in all these districts, and which especially especially recently are increasing rapidly, should also consider these types of contaminants to enable an effective fight against them and to ensure protection from their production quality and plant vitality.

4. Based on the data of Tab. no. 2 as well as in the conclusion reached in point 7 of the above conclusions the chemical fight against these parasites would be effective if it takes place in the spring-summer period.

\section{REFERENCE}

[1]. ARHANGELSKAJA,A. D. (1974) - Koksidi arjednjej Azii Tashkjent. Moskva (Leningrad). [2]. AVJERINCJEV,S.V.(1952) - Zoologia bjespozvonoçnih Sovjetskaja nauka. Moskva (Len.) [3]. BALASHOVSKI,A. et MESNIL,L. (1935;1936) - Les insektes. Nusibles auks kultivees Tom. I,II. Paris (Francë).

[4]. BAÇI, M. (1954) - Dëmtuesit kryesor të kulturave të arave e atyre frutorë. Tiranë.

[5]. BETH (Dr.) GRAFTON - CARDWELL (2003) - Stages of cottony cushion scale (Icerya purchase) and its natural enemy the vedalia beetle (Rodolia cardinalis).

[6]. BORROL and DE LONG'S (2017 ) - Introduction to the study of insects (7th ed.). Australia: Thomson, Brooks/Cole. ISBN 9780030968358. http://www.biology-online 898 bytes (94 words) - 00:50, 3 April 2017

[7]. BORHKSENIUS, N. S. (1950) - Sbor i izuçienije çjervjeçov i shçitovok, Moscva.

[8]. BORHKSENIUS, N. S. (1964) - Oprjedjelitjel nasjekomih evropjejskoi çasti SSSR. Tom I. Moskva.

[9]. BORHKSENIUS, N. S. (1949) - Fauna SSSR. Nasjekomij e hobotni. Tom VII Pogotr. çjervjeçij i shçitovki (koksoidea) sjemjejstvo muçnistije çjervjeçi (Pseudokoksidae). Moskva.

[10]. BORHKSENIUS, N. S. (1949) - Oprjedjelitjel çervjeçi i shçitovki (koksoidea), Armenii, Erjevan.

[11]. BORHKSENIUS, N. S. (1950) - Çervjeçij i shçitovki SSSR (Koksoidea Opredjelitjeli po faunje SSSR, izdavajemije. Zoologiçjeskim institutom Akadjemii Nauk SSSR Nr.32.1), Moscva. [12]. BORHKSENIUS, N. S. (1937) - Oprjedjelitjel koksid (koksidae) vrjedjashçik kulturnim rastjenijam i ljesu.II. Moskva.

[13]. BORHKSENIUS, N. S. (1950) - Çjervjeçi i shçitovki SSSR (koksoidea), Moscva.

[14]. BORHKSENIUS, N. S. (1957) - Fauna SSSR. Nasjekomije hobotni. Tom IX Pogotr. çjervjeçi i shçitovki (koksoidea) sjemjestvo podushjeçnshçi i llozhnoshçitovki (koksidae). Moskva.

[15]. BORHKSENIUS, N. S. (1973) - Praktiçjeskij oprjedjelitjel koksid (Coccoidea) kulturnih rastjenij i ljesnih porod SSSR. Leningrad.

[16]. BORHKSENIUS, N. S. (1966) - Katalog shçitovok (Diaspidoidea). Mirovoj fauni. Izdastjelstvo "Nauka". Moskva. Ljeningrad.

[17]. ÇELOALIAJ, Q. (1987) - Speciet e breshkëzave të përhapura në agrume në zonën e Vlorës e Sarandës. Instituti i agrumeve dhe ullirit . Vlorë. 
[18]. DOGJEL,V.A; (EZHIKOV， I. I.) (KUZNJECOV， N. JA.); PJEGCTOV， D. N; FILATOVA, Z. A. (1951) - Rukovodstvo po zoologii tom trjetij, çast ftoraja; bjespozvonoçnije pod rjedakcijej Ll.A.Zjenkjeviça. Sovjetskaja nauka Moskva.

[19]. GAXHO, S. (1965) - Kontribut në studimin e breshkëzës së kuqe të agrumeve. (Chrysomphalus dictyospermi Morg.) dhe mbi disa prova të luftimit të saj. BUSHT. Seria e Shkencave Natyrore Nr.3. Tiranë.

[20]. HASANI N. L. (1997) - Koksidet.Tiranë.

[21]. HASANI N. L. (1999) - Përcaktues insektesh. Çelës-Atlas. Tiranë.

[22]. KAFAZI, N. (1966) - Kultivimi i agrumeve. Tiranë.

[23]. KALTANI, T.; STANI, A. (1973) - Sëmundjet dhe dëmtuesit e ullirit, agrumeve, fiqve, kajsisë dhe nespullës. Tiranë.

[24]. KAPIDANI, A.; PRIFTI, M.; JAÇO, N. (1982) - Entomologjia bujqësore. (Pjesa e përgjithshme, dëmtuesit e bimëve). Tiranë.

[25]. KOSTA, C; BENASSY (1981) - Radha e punës për përgatitjen e mikropreparateve entomologjike. Londër. Angli.

[26]. LAMANI, F. (1981) - Teknika e përgatitjes së koleksioneve zoologjike. Tiranë.

[27]. MURRA, XH. (1981) - Dëmtuesit kryesorë të kulturave. Tiranë.

[28]. MINIHSTERSTVO SJELLSKOVO HORJAJSTVA SOJUZA SSR, OTDJELL PO KARANTINI SJELSKOHOZJAJSTBJENNIH RASTJENIJ, ÇENTRALNAJA LLABORATORIJA PO KARANTINI SJELSKOHOZJAJSTBJENNIH RASTJENIJ (1948) Illjustrirovanij spravoçnik po vreditjeljam i boljeznjam vnjeshn jevo karatina. SSSR Moskva.

[29]. RUBCOV, I. A. (1954) - Vrjeditjeli citrusovih i ih jestjestvjenije vragi. Moskva.

[30]. SHVANVIÇ, B. N. (1949) - Kurs obshçjej entomologii. Moskva.

[31]. .......................(1988) - Manual agroklimatik i rrethit të Vlorës. Instituti hidrometeorologjik. Akademia e Shkencave të Republikës së Shqipërisë. Tiranë.

[32]. ......................... (1964) - Oprjedjelitjel nasjekomih evropjejskoj çasti SSSR V pjati tomah I. Nizshije, drjevnjekrilije, s njepolnim prjevrashçjenijem. Moskva. Ljeningrad.

[33]. (1948) - Oprjedjelitjel nsjekomih evropjejskoj çasti SSSR. Moskva.

[34]. (1987) - Veçoritë agroklimatike të rrethit të Vlorës. Akademia e Shkencave e Republikës së Shqipërisë. Instituti Hidrometeorologjik. Tiranë.

[35].https://aasf.com.al/wp-content/uploads/2019/06/Agrumet Press.pdf (Studim për sektorin e agrumeve) - Prof. Dr. Engjëll Skreli / Prof. Assoc. Dr. Drini Imami - Instituti i Studimeve Ekonomike dhe Transferimit të Njohurive - Tiranë, 2019

[36].https://po.al/mandarinat-e-sarandes-kalojne-kufijte-shqiperia-e-teta-ne-evrope-perprodhimin-e-agrumeve/ 